\title{
ANÁLISE MORFOAGRONÔMICA E MOLECULAR DAS CULTIVARES DE CAFÉ DO IFES CAMPUS DE ALEGRE
}

Fernanda Vargas Valadares ${ }^{1}$, Raiane Mariani Santos ${ }^{1}$, Iris Petronilia Dutra², José Dias de Souza $\mathrm{Neto}^{3}$, Monique Moreira Moulin ${ }^{4}$.

1'Graduada em Licenciatura em Ciências Biológicas do Instituto Federal do Espírito Santo Campus de Alegre.

${ }^{2}$ Graduanda em Tecnólogo em Cafeicultura do Instituto Federal do Espírito Santo Campus de Alegre.

3 Técnico Mestre do Instituto Federal do Espírito Santo Campus de Alegre.

${ }^{4}$ Professora Doutora do Instituto Federal do Espírito Santo Campus de Alegre,

Brasil. Email:moniquemoulin@gmail.com

Recebido em: 08/04/2016 - Aprovado em: 30/05/2016 - Publicado em: 20/06/2016 DOI: 10.18677/Enciclopedia_Biosfera_2016_008

\begin{abstract}
RESUMO
O café é uma das espécies mais cultivadas e comercializadas do mundo. O estudo morfoagronômico e molecular é muito útil para análise da diversidade genética, sendo importante para o conhecimento e uso da cultura. Os objetivos do presente trabalho foram: i) realizar a caracterização morfoagronômica e por intermédio desta estimar a divergência genética de cultivares de café, e ii) selecionar o método de extração de DNA mais eficiente e os iniciadores adequados para a caracterização molecular das cultivares de café. A pesquisa foi realizada nas lavouras de café do Parque Cafeeiro do Ifes Campus de Alegre, com oito cultivares, sendo cinco arábicas ( $C$. arabica L.) e três conilon ( $C$. canephora P.). As cultivares foram caracterizadas por descritores morfoagronômicos específicos para o gênero Coffea. Para as análises moleculares de DNA foram testados cinco protocolos de extração, e após escolha do protocolo adequado, foi realizada triagem com dez ISSR com o intuito de averiguar o polimorfismo gerado. As análises estatístico-genéticas das características morfoagronômicos quantitativas foram realizadas com auxílio do programa Genes e o agrupamento obtido pelo método UPGMA. Para as análises moleculares, foi realizado ANOVA das concentrações de DNA seguida pelo teste $F$. Para os caracteres quantitativos foi observada uma boa divergência genética. $\mathrm{Na}$ análise qualitativa foi constatado um baixo número de classes, o que evidencia uma alta uniformidade das cultivares para os caracteres avaliados. Três protocolos de extração de DNA apresentaram boas concentrações de DNA, e foram selecionados cinco iniciadores com melhores perfis eletroforéticos e bandas de DNA mais nítidas.
\end{abstract}

PALAVRAS-CHAVE: Coffea. Diversidade genética. Parque Cafeeiro. 


\title{
ANALYSIS OF MOLECULAR AND MORPHOAGRONOMIC IFES GAY CAMPUS COFFEE CULTIVARS
}

\begin{abstract}
Coffee is one of the most cultivated species and marketed the world. The morfoagronômico and molecular study is very useful for analysis of genetic diversity is important for the knowledge and use of culture. The objectives of this study were: i) perform morphoagronomic and through characterization of this estimate the genetic divergence of coffee cultivars, and ii) select the most efficient DNA extraction method and primers suitable for the molecular characterization of coffee cultivars. The survey was conducted in coffee plantations of the Coffee Park IFES Campus Alegre with eight cultivars, five Arabica (Coffea arabica L.) and three conilon ( $C$. canephora P.). The cultivars were characterized by specific morphological descriptors for the genus Coffea. For the molecular analysis of DNA were tested five extraction protocols and after selecting the appropriate protocol, screening was performed with ten ISSR in order to ascertain the generated polymorphism. The statistical-genetic analysis of quantitative morphological characteristics were performed using the program Genes and the group obtained by the UPGMA method. For molecular analysis, ANOVA was performed of DNA concentrations followed by $F$ test for the quantitative traits a good genetic divergence was observed. Qualitative analysis was found a low number of classes, which shows a high uniformity of the cultivars for the traits. Three DNA extraction protocols showed good DNA concentrations, and we selected five primers best electrophoretic profiles and sharper DNA bands.
\end{abstract} KEYWORDS: Coffea. Genetical diversity. Coffee Park.

\section{INTRODUÇÃO}

O café é nativo das regiões tropicais da América do Sul, Ásia e África. Pertence ao gênero Coffea da família Rubiaceae. Este gênero é composto por cinco grupos distintos, porém apenas o grupo Eucoffea contém espécies que apresentam importância comercial, o Coffea arabica Linn (café arábica) e o Coffea canephora Pierre (café conilon) (RONCAL et al., 2015).

O Brasil é o maior produtor e exportador mundial de café (JACOMINI et al., 2015), sendo que os estados de Minas Gerais e do Espírito Santo destacam-se como maiores produtores nacionais de café arábica e café conilon, respectivamente (FERRÃO et al., 2015).

O cafeeiro apresenta variabilidade em relação às características morfológicas de folhas, flores e frutos, aos caracteres agronômicos, moleculares e bioquímicos, haploidia e reprodução (AGUIAR et al., 2004). Para um estudo a cerca da diversidade genética é importante uma análise das características morfoagronômicas e moleculares. A caracterização de café é de fundamental importância para o conhecimento e uso dos acessos (DIAS et al., 2015).

Os descritores morfoagronômicos e de DNA são utilizados para disponibilização de informações de cultivares e atuam de forma complementar. Estas duas técnicas aliam a descrição do fenótipo e do genótipo, respectivamente, possibilitando a distinção de fenótipos morfologicamente similares, mas geneticamente diferentes (HEALEY et al., 2014).

A caracterização morfoagronômica e molecular de cultivares de café são importantes porque a planta apresenta base genética estreita, sendo difícil e 
complexa a discriminação fenotípica e a identificação de acessos específicos em um banco de germoplasma (DIAS et al., 2015).

O fundamento do melhoramento genético tradicional do cafeeiro é constituído pela seleção genética com base em dados fenotípicos avaliados em campo, tanto para definir novos cruzamentos a serem realizados, com o intuito de gerar novos genótipos, como na identificação dos melhores indivíduos a serem usados comercialmente (FERRÃO et al., 2015).

A extração de DNA para a caracterização molecular de cultivares de café é considerada complexa devido o cafeeiro ser uma planta sujeita a muita oxidação, principalmente nas folhas e nos frutos. Compostos fenólicos como o ácido 5cafeoilquínico, também conhecido como ácido clorogênico (CGA), principal substrato da polifenoloxidase (PFO) estão presentes em quantidades expressivas nesses tecidos e, em geral, prejudicam a extração de DNA (PEREIRA et al., 2009).

Os objetivos do presente trabalho foram: i) realizar a caracterização morfoagronômica e por intermédio desta estimar a divergência genética de cultivares de café presentes no Parque Cafeeiro do Ifes, Campus de Alegre, e ii) selecionar o método de extração de DNA mais eficiente e os iniciadores adequados para a caracterização molecular das cultivares de café.

\section{MATERIAL E MÉTODOS}

A pesquisa foi realizada nas lavouras de café do Parque Cafeeiro do Instituto Federal do Espírito Santo (Ifes) - Campus de Alegre, com oito cultivares, sendo cinco arábicas (C. arabica L.) e três conilon (C. canephora $P$.) (Quadro 1). O Ifes Campus de Alegre fica localizado no município de Alegre, ES, Brasil, nas coordenadas

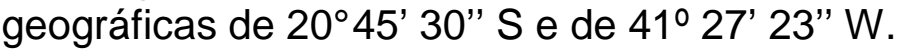

QUADRO 1. Espécies e cultivares de cafés ( $C$. arabica e $C$. canephora) do Parque Cafeeiro do Ifes, Campus de Alegre.

\begin{tabular}{cc}
\hline Espécie & Cultivar \\
\hline C. arabica & 'Catuaí amarelo' \\
C. arabica & 'Catuaí vermelho' \\
C. arabica & 'Obatã' \\
C. arabica & 'Topázio' \\
C. arabica & 'Tupi' \\
C. canephora & 'Robustão' \\
C. canephora & 'Robusta Tropical' \\
C. canephora & 'Vitória' \\
\hline
\end{tabular}

Fonte: acervo pessoal dos autoes, 2015.

\section{Caracterização morfoagronômica}

As cultivares foram caracterizadas por descritores morfoagronômicos essenciais específicos para o gênero Coffea, altamente discriminantes, que estão disponíveis em International Plant Genetic Resources Institute (IPGRI, Descriptors for Coffee, 1996). Para a caracterização morfoagronômica as cultivares de café foram identificadas e coletadas no período de junho a agosto de 2015, e foram avaliadas seis repetições de cada cultivar. Foram utilizados doze descritores, sendo 
cinco quantitativos e sete qualitativos multicategóricos, sendo analisados de acordo com a tabela abaixo (Quadro 2).

QUADRO 2. Descritores utilizados para caracterização morfoagronômica.

\begin{tabular}{|c|c|}
\hline Descritor & Análise \\
\hline Altura da planta (AP) & $\begin{array}{l}\text { mensurado com trena metálica a maior } \\
\text { altura da planta em } \mathrm{m} \text {. }\end{array}$ \\
\hline Comprimento da folha (CF) & $\begin{array}{l}\text { mensurado com régua o maior } \\
\text { comprimento da folha em } \mathrm{cm} \text {. }\end{array}$ \\
\hline Comprimento do pecíolo (CP) & mensurado com régua o maior \\
\hline Diâmetro do caule (DC) & $\begin{array}{l}\text { comprimento do pecíolo em } \mathrm{cm} \text {. } \\
\text { mensurado com paquímetro o maior } \\
\text { diâmetro do caule em } \mathrm{cm} \text {. }\end{array}$ \\
\hline Largura da folha (LF) & $\begin{array}{l}\text { mensurado com régua a maior largura } \\
\text { da folha em } \mathrm{cm} .\end{array}$ \\
\hline Cor da folha jovem (CFJ) & $\begin{array}{l}\text { Analisada de acordo com uma escala de } \\
\text { notas: (1) verde-claro; (2) verde; (3) } \\
\text { acastanhado; (4) castanho avermelhado; } \\
\text { (5) bronze; } 6 \text { ) outros. }\end{array}$ \\
\hline Cor da gema jovem (CGJ) & $\begin{array}{c}\text { Analisada de acordo com uma escala de } \\
\text { notas: (1) verde; (2) marrom-escuro; (3) } \\
\text { outros. }\end{array}$ \\
\hline Cor do pecíolo (COP) & $\begin{array}{c}\text { Analisada de acordo com uma escala de } \\
\text { notas: (1) verde; (2) marrom-escuro; (3) } \\
\text { outros. }\end{array}$ \\
\hline Dominância da pilosidade (DP) & $\begin{array}{l}\text { Analisada de acordo com uma escala de } \\
\text { notas: (1) dispersa; (2) intermediária; (3) } \\
\text { densa. }\end{array}$ \\
\hline Forma da folha (FF) & $\begin{array}{l}\text { Analisada de acordo com uma escala de } \\
\text { notas: (1) abóbada ; (2) ovalada; (3) } \\
\text { elíptica ; (4) lanceolada; (5) outras. }\end{array}$ \\
\hline $\begin{array}{l}\text { Forma da folha de acordo com ápice } \\
\qquad \text { (FFA) }\end{array}$ & $\begin{array}{l}\text { Analisada de acordo com uma escala de } \\
\text { notas: (1) redonda; (2) obtusa; (3) } \\
\text { aguda; (4) aculeada; (5) apiculada; (6) } \\
\text { espatulada; (7) outras. }\end{array}$ \\
\hline Posição da inflorescência (PI) & $\begin{array}{c}\text { Analisada de acordo com uma escala de } \\
\text { notas: (1) axial; (2) terminal. }\end{array}$ \\
\hline
\end{tabular}

Fonte: acervo pessoal dos autores , 2015.

\section{Análise Molecular}

As análises moleculares foram realizadas no Laboratório de Biologia Molecular e Genética do Ifes Campus de Alegre no período de julho a outubro de 2015, conforme as etapas descritas abaixo.

\section{Preparo Das Amostras}

Folhas jovens, sadias e em fase ativa de crescimento foram coletadas logo nas primeiras horas da manhã. Isso porque as plantas mantidas no escuro 
acumulam menor teor de polifenóis (MOSLEMI et al., 2013). As folhas correspondentes a cada cultivar de café foram enroladas em papel alumínio, identificadas e imediatamente mergulhadas em $\mathrm{N}_{2}$ líquido para que não ocorresse a degradação do DNA. Uma vez no laboratório, este material foi macerado em nitrogênio líquido até formar um pó bastante fino.

\section{Extração do DNA}

Foi realizado um ensaio prévio de forma a selecionar o melhor tipo de acondicionamento do material vegetal e protocolo que apresentasse quantidade e pureza de DNA elevadas, devido à grande quantidade de polifenóis presentes nas folhas de café, que em geral, prejudica a extração. Para isso, foram selecionados cinco protocolos segundo busca em literatura científica (Tabela 1).

TABELA 1. Metodologias de extração de DNA e formas de armazenamento foliar utilizados em ensaio de qualidade e quantidade de DNA.

\begin{tabular}{|c|c|c|c|}
\hline Código & Artigo & Armazenamento & Repetição \\
\hline \multirow{6}{*}{1} & \multirow{6}{*}{$\begin{array}{l}\text { DOYLE E DOYLE (1990), } \\
\text { modificado por Abdelnoor } \\
\text { (1995) }\end{array}$} & & 1 \\
\hline & & C & 2 \\
\hline & & & 3 \\
\hline & & & 1 \\
\hline & & $\mathrm{N}$ & 2 \\
\hline & & & 3 \\
\hline \multirow{6}{*}{2} & \multirow{6}{*}{$\begin{array}{l}\text { DOYLE E DOYLE (1990) } \\
\text { modificado por IAC }\end{array}$} & & 1 \\
\hline & & C & 2 \\
\hline & & & 3 \\
\hline & & & 1 \\
\hline & & $\mathrm{N}$ & 2 \\
\hline & & & 3 \\
\hline \multirow{6}{*}{3} & \multirow{6}{*}{ SERENO et al. (2006) } & & 1 \\
\hline & & C & 2 \\
\hline & & & 3 \\
\hline & & & 1 \\
\hline & & $\mathrm{N}$ & 2 \\
\hline & & & 3 \\
\hline \multirow{6}{*}{4} & \multirow{6}{*}{ HEALEY et al. (2014) } & & 1 \\
\hline & & C & 2 \\
\hline & & & 3 \\
\hline & & & 1 \\
\hline & & $\mathrm{N}$ & 2 \\
\hline & & & 3 \\
\hline \multirow{6}{*}{5} & \multirow{6}{*}{ PEREIRA et al. (2009) } & & 1 \\
\hline & & C & 2 \\
\hline & & & 3 \\
\hline & & & 1 \\
\hline & & $\mathrm{N}$ & 2 \\
\hline & & & 3 \\
\hline
\end{tabular}

Fonte: acervo pessoal dos autores, 2015. $\left(\mathrm{C}=\right.$ material congelado a $-18^{\circ} \mathrm{C} /$ sete dias; $\mathrm{N}=$ folhas coletadas momentos antes extração). 
Quanto ao material para extração, parte das folhas foram coletadas previamente, sendo armazenada em freezer $-18^{\circ} \mathrm{C}$ por uma semana, e outra parte foi colhida momentos antes da extração, com o intuito de avaliar a influência da forma de armazenamento na extração de DNA. Cada tratamento consistiu de três repetições (protocolo $\mathrm{x}$ material), segundo Tabela 3. Foi escolhida a cultivar 'Catuaí amarelo' para o ensaio prévio de protocolos, devido sua divergência fenotípica nas condições de campo. A extração de DNA do protocolo 1 foi realizada de acordo com as seguintes etapas:

$1^{\text {a }}$ etapa - Cerca de $200 \mathrm{mg}$ de tecido macerado foi transferido para tubos de $1,5 \mathrm{~mL}$, sendo realizado de forma rápida para evitar oxidação;

$2^{\text {a }}$ etapa - Foram adicionados aos tubos contendo as amostras, $700 \mu \mathrm{L}$ do tampão de extração pré-aquecido contendo CTAB $2 \%, \mathrm{NaCl} 1,4 \mathrm{~mol} \mathrm{~L}^{-1}$, EDTA 20 mmol L ${ }^{-1}$, Tris-HCl 100 mmol L $^{-1}$ (pH 8,0), PVP sólido $2 \%$ e $\beta$ - mercaptoetanol 0,2\%, estes dois últimos necessários para remoção dos compostos fenólicos;

$3^{\text {a }}$ etapa - os tubos foram incubados em banho maria a $65^{\circ} \mathrm{C}$ por $30-40$ minutos. Durante a incubação, os tubos foram suavemente homogeneizados a cada 10 minutos. O material foi colocado em temperatura ambiente durante um período de 20 minutos;

4⿳亠丷厂 etapa - Adicionou-se ao sobrenadante $700 \mu \mathrm{L}$ de clorofórmio:álcool isoamílico. Os microtubos foram agitados por inversões suaves, por aproximadamente 5 minutos até ficar turvo. A fase orgânica foi separada por centrifugações por 5 minutos a 14.000 rpm;

$5^{\circ}$ etapa - Procedeu-se a transferência da fase sup erior (aquosa) para um novo tubo devidamente identificado, tendo cuidado de não transferir a interfase e a fase inferior (foi transferido aproximadamente $350 \mu \mathrm{L}$ );

$6^{\circ}$ etapa - Foi adicionado isopropanol gelado ao so brenadante. Inversões suaves foram realizadas e o material incubado a $-20^{\circ} \mathrm{C}$, por 2 a 3 horas;

$7^{\circ}$ etapa - O material foi centrifugado por 10 minu tos a $14.000 \mathrm{rpm}$, sendo removido o sobrenadante. O precipitado resultante foi lavado uma vez com etanol $70 \%$ e uma vez com etanol $95 \%$. O precipitado foi seco a temperatura ambiente por 30 minutos; 8 8 $^{\text {a }}$ etapa - O precipitado foi ressuspenso em $200 \mu \mathrm{L}$ de tampão de extração contendo RNAse na concentração final de $40 \mathrm{mg} / \mathrm{mL}$, e em seguida, incubado em banho maria a $37^{\circ} \mathrm{C}$ por uma hora e meia. Ao final deste passo o DNA está ressuspenso na solução.

As condições de extração para os protocolos 2, 3, 4 e 5 seguiram da mesma forma descrita para o ensaio do protocolo 1, com as seguintes modificações (Tabela 2):

TABELA 2. Divergência entre reagentes, concentrações e procedimentos dos cinco protocolos utilizados.

\begin{tabular}{|c|c|}
\hline Protocolos & Divergência \\
\hline 1 & $\begin{array}{l}\text { PVP sólido } 2 \% \text {; } \beta \text {-mercaptoetanol } 0,2 \% \text {; centrifugação } 14.000 \mathrm{rpm} \text { e } \\
\text { incubação a } 65^{\circ} \mathrm{C} \text { por } 30-40 \text { minutos }\end{array}$ \\
\hline 2 & PVP sólido $1 \%$ e a centrifugação $12.000 \mathrm{rpm}$ \\
\hline 3 & $\begin{array}{l}\text { Incubação a } 55^{\circ} \mathrm{C} \text { por } 60 \text { minutos, e foi adicionado } 0.1 \mathrm{mg} \mathrm{mL}^{-1} \text { de } \\
\text { proteinase } \mathrm{K} \text { após a adição do tampão de extração }\end{array}$ \\
\hline 4 & $\beta$-mercaptoetanol $0,3 \%$ e NaCl foi $2,5 \mathrm{~mol} / \mathrm{L}$ \\
\hline 5 & $\begin{array}{l}\mathrm{pH} \text { do Tris } \mathrm{HCl} \text { foi } 7,5 \text {, e na lavagem do precipitado foram realizadas } \\
\text { duas lavagens com etanol } 70 \%\end{array}$ \\
\hline
\end{tabular}




\section{Quantificação e Amplificação do DNA}

Após a extração de DNA, as amostras foram quantificadas pelo equipamento QuiBit 2.0 Fluorometer, obtendo-se as concentrações de DNA. Em seguida, as amostras de um mesmo tratamento foram diluídas para $10 \mathrm{ng} / \mu \mathrm{L}$ e realizadas PCR para o iniciador UBC 890.

Foi utilizada a seguinte programação para as reações de amplificação: desnaturação inicial durante 15 min a $94{ }^{\circ} \mathrm{C}$; 35 cic los de 30 seg a $94{ }^{\circ} \mathrm{C}, 30$ seg a $52{ }^{\circ} \mathrm{C}$ e 1 min a $72{ }^{\circ} \mathrm{C}$; e um passo de extensão final durante 7 minutos a $72{ }^{\circ} \mathrm{C}$. Os produtos de reação foram separados por eletroforese em gel de poliacrilamida $10 \%$ imerso em tampão TBE 1X (89 mM base Tris, $89 \mathrm{mM}$ ácido bórico, EDTA 2,23 mM) sob tensão constante $(110 \mathrm{~V})$ durante $3 \mathrm{~h}$. Um marcador $100 \mathrm{pb}$ foi usado como controle positivo na etapa de coloração. A coloração foi efetuada com nitrato de prata $0,2 \%$, sendo fotografado com o uso do fotodocumentador Biorad $X R^{+}$.

Em seguida, as bandas de DNA de cada amostra foram observadas e averiguadas sua integridade. Sendo que o protocolo de extração considerado satisfatório foi o que apresentou maior número de bandas definidas, dentre os cinco protocolos e duas condições de armazenamento (congelado e natural).

\section{Seleção dos Iniciadores}

Após escolha do protocolo adequado, foi realizada a extração de DNA das oito cultivares de café. Para seleção dos iniciadores, foi realizada uma triagem com dez ISSR (University of British of Columbia - UBC, Vancouver, Canadá) (Tabela 3), com o intuito de averiguar o polimorfismo gerado. Foram escolhidos para triagem dois genótipos de café, sendo um de café arábica ('Catuaí Amarelo') e um de conilon ('Robustão'), que apresentam características morfológicas divergentes, e um de jabuticaba (controle positivo). As concentrações dos reagentes e condições para PCR seguiram da mesma forma descrita para os ensaios de teste dos protocolos.

TABELA 3. Identificação e sequência dos iniciadores ISSR utilizados no estudo.

\begin{tabular}{|c|c|}
\hline Nome & Sequência \\
\hline UBC 810 & $(\mathrm{GA})_{8} \mathrm{~T}$ \\
\hline UBC 813 & $(\mathrm{CT})_{8} \mathrm{~T}$ \\
\hline UBC 818 & $(\mathrm{CA})_{8} \mathrm{G}$ \\
\hline UBC 824 & $(\mathrm{TC})_{8} \mathrm{G}$ \\
\hline UBC 843 & $(\mathrm{CT})_{8} \mathrm{RA}$ \\
\hline UBC 845 & $(\mathrm{CT})_{8} \mathrm{RG}$ \\
\hline UBC 868 & $(\mathrm{GAA})_{6}$ \\
\hline UBC 889 & $\mathrm{DBD}(\mathrm{AC})_{7}$ \\
\hline UBC 890 & $\mathrm{DBD}(\mathrm{AC})_{7}$ \\
\hline UBC 859 & $(\mathrm{TG})_{8} R \mathrm{RG}$ \\
\hline
\end{tabular}

Fonte: acervo pessoal dos autores, 2015.

Os produtos da reação de PCR foram separados por eletroforese em gel de agarose a 2,5\% imerso em tampão TBE $1 \mathrm{X}$ sob tensão constante de $110 \mathrm{~V}$ durante $3 \mathrm{~h}$. Um marcador $100 \mathrm{pb}$ foi usado para distinguir e estimar a massa molecular dos fragmentos de DNA. A coloração foi realizada com brometo de etídio $(0,25 \mathrm{ng} / \mu \mathrm{L})$, sendo a imagem obtida com o uso de um fotodocumentador Biorad $X R^{+}$. 


\section{Análise Estatística}

As análises estatístico-genéticas das características morfoagronômicas foram realizadas com auxílio do programa Genes (CRUZ, 2008). A estimativa da matriz de distância genética por meio das variáveis quantitativas foi obtida com base na distância de Mahalanobis. O agrupamento dos acessos foi obtido pelo método Unweighted Paired Group Methodusing Arithmetic averages (UPGMA). Para as análises moleculares, foi realizado ANOVA das concentrações de DNA seguida pelo teste F.

\section{RESULTADOS E DISCUSSÃO}

\section{Caracterização Morfoagronômica}

Para os caracteres quantitativos foi observada elevada discrepância entre os valores mínimos e máximos (Tabela 4), o que evidenciou uma boa divergência genética entre as cultivares de café avaliadas.

TABELA 4. Médias das variáveis morfoagronômicas quantitativas das cultivares de café do Ifes Campus de Alegre.

\begin{tabular}{|c|c|c|c|c|c|c|}
\hline Espécie & Cultivar & $\mathrm{AP}(\mathrm{m})$ & $\mathrm{CF}(\mathrm{cm})$ & $\mathrm{CP}(\mathrm{cm})$ & $\mathrm{DC}(\mathrm{cm})$ & LF(cm) \\
\hline C. arabica & $\begin{array}{l}\text { 'Catuaí } \\
\text { amarelo' }\end{array}$ & $2,36 \pm 0,23$ & $14,48 \pm 0,49$ & $1,39 \pm 0,15$ & $\begin{array}{l}6,03^{ \pm} \\
0,73\end{array}$ & $6,34^{ \pm} 0,30$ \\
\hline C. arabica & $\begin{array}{c}\text { 'Catuaí } \\
\text { vermelho' }\end{array}$ & $2,24^{ \pm} 0,21$ & $13,56 \pm 0,46$ & $1,22 \pm 0,12$ & $6,35^{ \pm} 0,27$ & $5,64^{ \pm} 0,22$ \\
\hline C. arabica & 'Obatã’ & - & $15,31 \pm 0,44$ & $1,27^{ \pm} 0,09$ & $6,25^{ \pm} 0,24$ & $6,57^{ \pm} 0,74$ \\
\hline C. arabica & ‘Topázio’ & - & $13,46 \pm 0,56$ & $1,19^{ \pm} 0,16$ & $5,64 \pm 0,22$ & $5,85^{ \pm} 0,25$ \\
\hline C. arabica & ‘Tupi’ & $1,84^{ \pm} 0,28$ & $14,74^{ \pm} 0,69$ & $1,28^{ \pm} 0,10$ & $5,41{ }^{ \pm} 0,34$ & $6,38^{ \pm} 0,30$ \\
\hline $\begin{array}{c}\text { C. } \\
\text { canephora }\end{array}$ & 'Robustão' & $2,38^{ \pm} 0,27$ & $15,07 \pm 0,62$ & $1,49 \pm 0,20$ & $4,02 \pm 0,18$ & $6,48^{ \pm 0} 0,36$ \\
\hline $\begin{array}{c}\text { C.canepho } \\
\text { ra }\end{array}$ & $\begin{array}{l}\text { 'Robusta } \\
\text { Tropical' }\end{array}$ & $2,07^{ \pm} 0,18$ & $14,28^{ \pm} 1,50$ & $1,05^{ \pm} 0,09$ & $4,61 \pm 0,19$ & $6,05^{ \pm} 0,75$ \\
\hline $\begin{array}{c}\text { C. } \\
\text { canephora }\end{array}$ & 'Vitória' & $2,24^{ \pm} 0,16$ & $14,59 \pm 1,56$ & $1,18^{ \pm} 0,15$ & $3,44 \pm 0,23$ & $6,17^{ \pm} 0,64$ \\
\hline
\end{tabular}

AP: Altura da planta; CF: comprimento da folha; CP: comprimento do pecíolo; DC: diâmetro do caule; LF: largura da folha. Fonte: acervo pessoal dos autores, 2015.

Para a altura da planta foi obtida uma variação média de $1,84 \mathrm{~m}$ a $2,38 \mathrm{~m}$, sendo representados pelas cultivares 'Tupi' e 'Robustão', respectivamente. As cultivares 'Obatã' e 'Topázio' sofreram uma recepa (corte para possibilitar a renovação total da parte aérea da lavoura) dias antes desta pesquisa, por isso não foi avaliado o descritor altura da planta para estas e as mesmas não foram consideradas para a análise estatística.

DIAS et al. (2014) ressaltam que plantas com alturas superiores a 3,5 metros, dificultam a colheita mecanizada dos frutos da parte superior da planta, restando nas 
plantas, em média, $22 \%$ da carga pendente. Neste sentido, o melhoramento de café tem priorizado a seleção de cultivares café arábica e conilon de porte baixo. Entretanto podem havar correlações positivas entre altura de plantas de café e a produtividade. CARVALHO et al. (2010) destacam a altura como uma das características que apresentaram maior correlação fenotípica com a produtividade.

AGUIAR et al. (2004) ao estudarem nove cultivares de café encontraram variações de altura entre $1,54 \mathrm{~m}$ a $2,98 \mathrm{~m}$. Segundo os autores as cultivares de café arábica tendem a sofrer maiores variações no descritor altura da planta do que as cultivares de café conilon, pois as cultivares arábicas são mais influenciadas pelo ambiente.

O comprimento da folha variou de $13,46 \mathrm{~cm}$ a $15,31 \mathrm{~cm}$, sendo o menor observado para a cultivar 'Topázio' e o maior para 'Obatã. AGUIAR et al. (2004) constataram valores bastante abaixo ao obtido neste trabalho, relatando uma variação de $7,97 \mathrm{~cm}$ a $11,15 \mathrm{~cm}$.

Para a largura da folha a variação foi de $5,64 \mathrm{~cm}$ a $6,48 \mathrm{~cm}$ para as cultivares 'Catuaí Vermelho' e 'Robustão', respectivamente. Segundo TOMAZ et al. (2015), a área da superfície foliar de uma planta café é a base do rendimento potencial da cultura, o que indica que folhas de maiores extensões são favoráveis a produção, sendo desejável para a seleção de cultivares folhas de maior área foliar.

O comprimento e largura da folha estão relacionados à maior produtividade, pois uma maior área foliar implica em maior superfície de interceptação de luz, o que poderá resultar em taxas fotossintéticas mais elevadas e melhor conversão de carboidratos em grãos de café. Em geral, o café arábica possui folhas maiores que o café conilon, entretanto no presente trabalho os tamanhos de folhas foram muito similares, o que provavelmente está relacionado às condições climáticas da área de estudo, que é quente e seco.

Para o descritor comprimento do pecíolo foram encontrados valores de $1,05 \mathrm{~cm}$ a $1,49 \mathrm{~cm}$ para as cultivares 'Robusta Tropical' e 'Robustão', respectivamente. $\mathrm{O}$ diâmetro do caule variou entre $3,44 \mathrm{~cm}$ a $6,35 \mathrm{~cm}$, sendo que a cultivar 'Vitória' apresentou o menor diâmetro e a 'Catuaí Vermelho' o maior. MALLER et al. (2011) ao estudar duas cultivares de café no estado de Minas Gerais, encontraram valores de $3,78 \mathrm{~cm}$ e $4,06 \mathrm{~cm}$ para esse descritor.

Características morfológicas como o diâmetro do caule estão relacionadas a uma melhor absorção da água e nutrientes. Neste sentido, a maioria das cultivares possuem diâmetro superior a $3,00 \mathrm{~cm}$. Maller et al. (2011) destacam que há poucos trabalhos na literatura com recomendações específicas sobre diâmetro do caule para absorção de nutrientes e conversão em taxa de crescimento da planta.

No dendograma dos dados morfoagronômicos quantitativos, foram gerados quatro grupos distintos, com um corte a uma distância de 10 (Figura 1). Observou-se uma grande similaridade entre os genótipos 4-6 e 2-5, sendo considerados duplicatas para os caracteres quantitativos avaliados. Estes dois grupos encontramse também muito similares ao genótipo 1. Assim, estes cinco genótipos possuem pequeno percentual de dissimilaridade entre si, o que não ocorre com o genótipo 3 , que distancia-se dos materiais anteriores. 


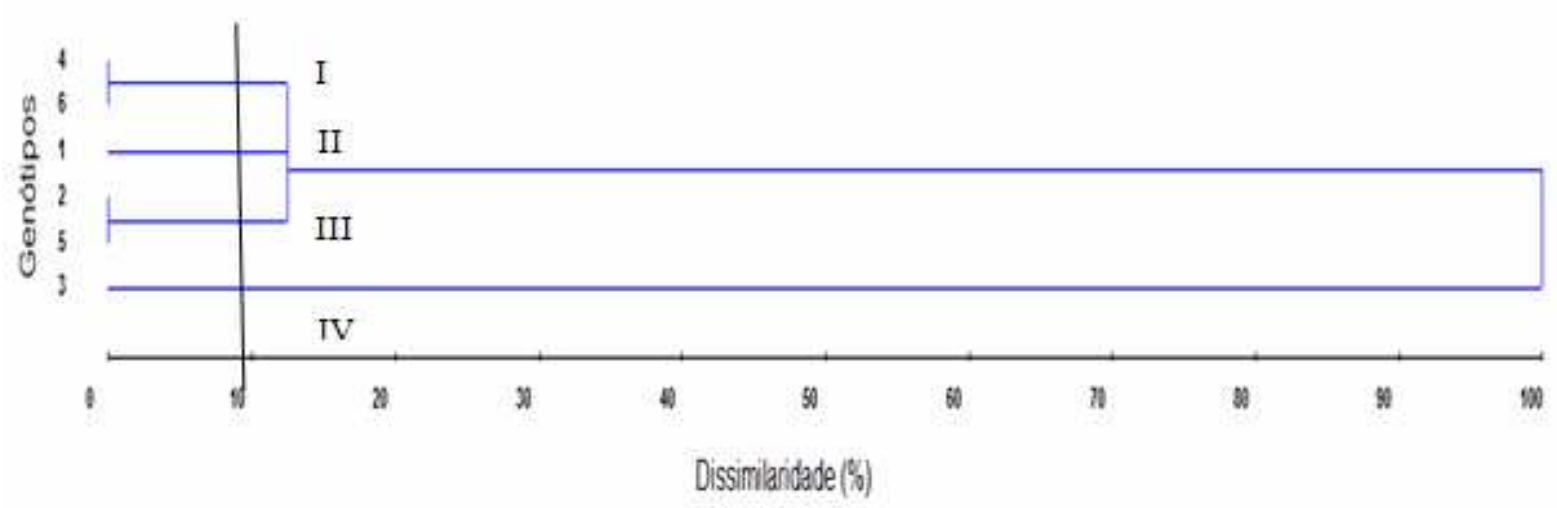

FIGURA 1 - Dendograma obtido pelo método UPGMA a partir da matriz de dissimilaridade entre seis cultivares encontradas no Parque Cafeeiro do Ifes Campus de Alegre. Cultivar 1 'Catuaí amarelo', cultivar 2 'Catuaí vermelho', cultivar 3 'Robustão', cultivar 4 'Robusta Tropical', cultivar 5 'Tupi' e cultivar 6 'Vitória'. Fonte: acervo pessoal dos autores , 2015.

O grupo I foi composto pelas cultivares 'Robusta Tropical' e 'Vitória' que se caracterizam por possuírem os menores comprimentos do pecíolo e diâmetro do caule. O grupo II compreendeu apenas a cultivar 'Catuaí Amarelo' que apresentou os valores altos de altura da planta e comprimento do pecíolo.

No grupo III foram alocados as cultivares 'Catuaí Vermelho' e 'Tupi' que apresentaram valores médios de comprimento de folha e comprimento de pecíolo. $O$ grupo IV, constituído apenas pelo cultivar 'Robustão', se diferenciou por apresentar de uma forma geral valores elevados para a maioria dos descritores.

O dendograma quantitativo agrupou as variedades de forma satisfatória, o que evidencia a eficácia das mensurações de características de herança quantitativa ou polimérica. Pode-se observar que as cultivares designadas como cultivar 4 ('Robusta Tropical') e cultivar 6 ('Vitória') foram alocadas em um mesmo grupo e pertencem a espécie $C$. Canephora, o mesmo ocorre com a cultivar 2 ('Catuaí vermelho') e a cultivar 5 ('Tupi') que também foram reunidas em um mesmo grupo, pertencem a espécie $C$. arabica, o que ressalta a similaridade entre as cultivares de mesma espécie. Conforme mostrado no dendograma a cultivar 1 ('Catuaí amarelo'), que é arábica, ficou disposta próxima ao grupo III. Apenas a cultivar 3 ('Robustão'), tipo conilon, apresentou-se mais distante, por apresentar os maiores valores para os descritores estudados.

$\mathrm{Na}$ análise qualitativa das cultivares foi observada um baixo número de classes, o que infere uma baixa diversidade genética e alta uniformidade das cultivares estudadas para os caracteres em análise. Descritores qualitativos geralmente são pouco discriminantes e sofrem influência do ambiente, o que ressalta a importância de se utilizar descritores quantitativos e moleculares, de forma a complementar as informações (WAHYUNI et al., 2013). Os descritores quantitativos ou poliméricos descrevem as cultivares com maior eficiência, mas possuem baixa herdabilidade e são bastante influenciáveis pelo ambiente.

As variáveis qualitativas analisadas foram uniformes, o que é justificável segundo alguns autores devido à base genética estreita do café, além de as cultivares serem fenotipicamente muito padronizadas para atender a demandas de produção e mercado. MALLER et al. (2011) também constataram que as características qualitativas não foram eficientes na discriminação de cultivares de 
café. Descritores qualitativos geralmente são pouco discriminantes e sofrem influência do ambiente, o que ressalta a importância de se utilizar descritores quantitativos e moleculares, de forma a complementar as informações

Para os descritores cor da folha jovem, cor da gema jovem e cor do pecíolo não foi observada variabilidade fenotípica, sendo o verde a única coloração constatada. Características como a cor da folha jovem e cor do pecíolo em café são determinadas pela expressão de um gene com dominância incompleta e apresenta alta herdabilidade, e por esse motivo, em geral, as folhas jovens e pecíolos são verdes. AGUIAR et al. (2004) encontraram em estudo duas variações na cor da folha jovem, verde e bronze, e para os outros descritores foi observada apenas a coloração verde, em concordância com os dados obtidos neste trabalho.

Para o descritor dominância da pilosidade foi constatado apenas o tipo disperso. Para a forma da folha foi encontrada a forma lanceolada. Em concordância MALLER et al. (2011) constataram a forma lanceolada para os mesmos cultivares de café arábica deste estudo, exceto para o 'Tupi', que apresentou formato elíptico. Para a forma da folha de acordo com ápice foi verificado a forma aculeada. E para a posição da inflorescência encontrou-se a posição axial.

As variáveis qualitativas analisadas foram uniformes, o que é justificável segundo alguns autores devido à base genética estreita do café, além de as cultivares serem fenotipicamente muito padronizadas para atender a demandas de produção e mercado (DIAS et al., 2015). Na literatura outros estudos constataram alta discriminância das cultivares de café com base nos caracteres quantitativos e grande uniformidade para os caracteres qualitativos, podendo ser detectada, visualmente, pequena ou nenhuma variação entre as cultivares (AGUIAR et al., 2004; MALLER et al., 2011).

\section{Extração de DNA e Seleção de Iniciadores}

Para os cinco métodos de extração foram obtidas a concentração de DNA por amostra, a média por tratamento, coeficiente de variação (CV) e os valores de teste $\mathrm{F}$ (Tabela 5).

TABELA 5: Protocolos utilizados em ensaio de qualidade e quantidade de DNA de café para duas formas de armazenamento foliar. $\left(\mathrm{C}=\right.$ material congelado a $-18^{\circ} \mathrm{C} /$ sete dias; $\mathrm{N}=$ folhas coletadas momentos antes extração).

\begin{tabular}{|c|c|c|c|c|c|c|c|}
\hline Código & Artigo & $\begin{array}{l}\text { Armazenamen } \\
\text { to }\end{array}$ & Repetição & $\begin{array}{c}\text { Concentraçã } \\
0\end{array}$ & Média & CV & $F$ \\
\hline \multirow{6}{*}{1} & \multirow{6}{*}{$\begin{array}{c}\text { DOYLE E } \\
\text { DOYLE } \\
(1990) \\
\text { modificado } \\
\text { por } \\
\text { ABDELNO } \\
\text { OR (1995) }\end{array}$} & \multirow{3}{*}{ C } & 1 & 0.1950 & & & \multirow{6}{*}{$\begin{array}{c}12.470 \\
6\end{array}$} \\
\hline & & & 2 & 0.1570 & 0.16133 & 0.19663 & \\
\hline & & & 3 & 0.1320 & & & \\
\hline & & \multirow{3}{*}{$\mathrm{N}$} & 1 & 0.0693 & \multirow{3}{*}{0.07737} & \multirow{3}{*}{0.45625} & \\
\hline & & & 2 & 0.1160 & & & \\
\hline & & & 3 & 0.0468 & & & \\
\hline \multirow{6}{*}{2} & \multirow{6}{*}{$\begin{array}{l}\text { DOYLE E } \\
\text { DOYLE } \\
\text { (1990) } \\
\text { modificado } \\
\text { por IAC }\end{array}$} & & 1 & 0.3090 & \multirow{3}{*}{0.45267} & \multirow{3}{*}{0.59818} & \multirow{6}{*}{0.4505} \\
\hline & & C & 2 & 0.7650 & & & \\
\hline & & & 3 & 0.2840 & & & \\
\hline & & & 1 & 0.3900 & \multirow{3}{*}{0.47633} & \multirow{3}{*}{0.45909} & \\
\hline & & $\mathrm{N}$ & 2 & 0.7250 & & & \\
\hline & & & 3 & 0.3140 & & & \\
\hline 3 & SERENO & C & 1 & 0.1060 & 0.05657 & 0.84969 & 6.6693 \\
\hline
\end{tabular}




\begin{tabular}{|c|c|c|c|c|c|c|c|}
\hline & \multirow[t]{4}{*}{$\begin{array}{l}\text { et al., } \\
2006 .\end{array}$} & & 2 & 0.0537 & \multirow{4}{*}{0.58267} & \multirow{4}{*}{0.68724} & \\
\hline & & \multirow{3}{*}{$\mathrm{N}$} & 1 & 1.0200 & & & \\
\hline & & & 2 & 0.4940 & & & \\
\hline & & & 3 & 0.2340 & & & \\
\hline \multirow{3}{*}{4} & \multirow{3}{*}{$\begin{array}{l}\text { HEALEY } \\
\text { et al., } \\
2014 .\end{array}$} & \multirow[t]{3}{*}{ C } & $\begin{array}{l}1 \\
2 \\
3\end{array}$ & $\begin{array}{l}0.0090 \\
0.0100 \\
0.0080\end{array}$ & 0.00900 & 0.11111 & \multirow{3}{*}{-0.3333} \\
\hline & & & $\begin{array}{l}1 \\
2\end{array}$ & 0.0111 & \multirow{2}{*}{0.00957} & \multirow{2}{*}{0.14037} & \\
\hline & & & 3 & 0.0090 & & & \\
\hline \multirow{6}{*}{5} & \multirow{6}{*}{$\begin{array}{l}\text { PEREIRA } \\
\text { et al., } \\
2009 .\end{array}$} & & 1 & 1.4400 & & & \multirow{6}{*}{$\begin{array}{c}16.592 \\
8\end{array}$} \\
\hline & & C & 2 & 1.9900 & 1.42800 & 0.39783 & \\
\hline & & & 3 & 0.8540 & \multirow{4}{*}{0.31767} & & \\
\hline & & & 1 & 0.5790 & & \multirow{3}{*}{0.85126} & \\
\hline & & $\mathrm{N}$ & 2 & 0.3350 & & & \\
\hline & & & 3 & 0.0390 & & & \\
\hline
\end{tabular}

Fonte: acervo pessoal dos autores , 2015.

Foi constatado que os protocolos 2, 3 e 5 apresentaram as maiores concentrações de DNA, com médias de 0.452 e 0.476 para folhas congeladas e natural para protocolo 2, 0.582 para folha natural do protocolo 3, e 1.428 para folhas congeladas do protocolo 5. MOSLEMI et al. (2013) avaliaram quatro metodologias de extração de DNA para 15 amostras de romãs e verificaram que o protocolo adaptado para maiores quantidades de CTAB, proteinase $K$, PVP e 2mercaptoetanol foram os que apresentaram maiores quantidade e qualidade do DNA, visto a redução de contaminantes na amostra, como polifenóis e polissacarídeos. No presente estudo, foi observado que a adição de proteinase $\mathrm{K}$ (protocolo 3) também favoreceu a quantidade e qualidade de DNA obtida.

Com relação aos protocolos que apresentaram as maiores médias de concentração de DNA (2, 3 e 5) o menor valor de coeficiente de variação foi para o tratamento com folha congelada no protocolo $5(39,78 \%)$, isso significa que o DNA obtido a partir do material congelado neste protocolo é o mais homogêneo dentre os testados. Estudo similar foi realizado por PEREIRA et al. (2009), no qual foi constatado que o armazenamento de folhas do cafeeiro possibilitou a obtenção de um DNA de melhor qualidade quando comparado ao DNA obtido na extração realizada logo após a coleta do material.

Com relação ao valor do teste $F$ para a hipótese independência do tipo de armazenamento da folha e quantidade de DNA por protocolo, verifica-se que para as metodologias 1,3 e 5 os valores foram de $12.4706,6.6693$ e 16.5928 respectivamente (Tabela 8 ). Estes valores são maiores que o valor crítico da tabela $\mathrm{F}$, que é de 4.545. Isso demonstra que o tipo de folha, juntamente com o protocolo, influenciam diretamente na quantidade de DNA extraído, e que estas variáveis devem ser levadas em conta antes da extração.

O protocolo 2 apresentou poucas diferenças para concentração de DNA em relação ao tipo de armazenamento do tecido utilizado, como pode ser visualizado pela pequena divergência no valor do coeficiente de variação do protocolo. Assim, este protocolo independe do tipo de armazenamento do tecido, o que dá certa 
liberdade para armazenar o material em freezer, evitando retorno ao local de coleta quando necessária uma nova extração.

Contudo, pela análise conjunta destes dados em comparação com o gel obtido (Figura 2), verifica-se que o protocolo 3, apesar de possuir menor concentração de DNA entre os três protocolos (2, 3 e 5), e maior valor de coeficiente de variação, foi o que apresentou bandas mais nítidas em comparação com os demais protocolos, o que pode estar relacionado a adição de proteinase K. Assim, o parâmetro concentração de DNA não pode ser absoluto na escolha da metodologia de extração de uma espécie, pois a pureza do material extraído e demais componentes celulares podem estar presentes. Além disso, as análises moleculares em café são limitadas devido à presença de polifenóis e pigmentos que interferem severamente na purificação do DNA, e nesse sentido, a proteinase $\mathrm{K}$ é muito útil para remoção dessas moléculas (MOULIN et al., 2012).

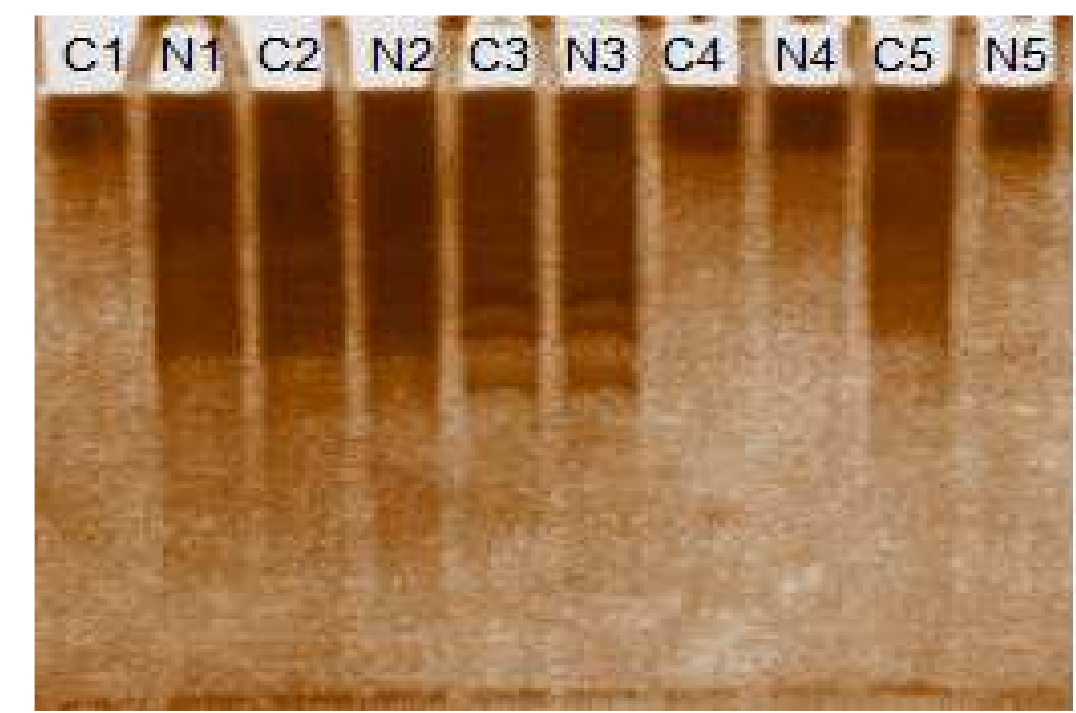

FIGURA 2: Teste de amplificação de ISSR UBC 890 para qualidade de amostras de DNA para protocolo $X$ material. Números correspondem a protocolos e letras a material congelado $(\mathrm{C})$ e natural $(\mathrm{N})$. Fonte: acervo pessoal dos autores , 2015.

Foi selecionado o protocolo 3 para extração das oito cultivares de café, devido a melhor nitidez das bandas de DNA. Procedeu-se a triagem dos iniciadores a serem utilizados para posteriores estudos de diversidade entre as cultivares, dos dez iniciadores ISSR utilizados, para duas amostras de cafeeiro (cultivar 'Catuaí Amarelo' e 'Robustão') e uma de jabuticabeira (controle), os iniciadores UBC 813, $818,824,845$ e 859 apresentaram melhores perfis eletroforéticos com maior polimorfismo e bandas de DNA mais nítidas para os três indivíduos (Figura 3). Dessa forma, estes são os mais indicados em estudos de diversidade genética, contudo todos os iniciadores podem ser utilizados para caracterização molecular das cultivares de café, por apresentarem bandas polimórficas. BORÉM \& CAIXETA (2009) ressaltam que um polimorfismo elevado abrange um maior número de regiões gênicas, permitindo obtenção de um maior quantitativo de informações dos materiais trabalhados. 


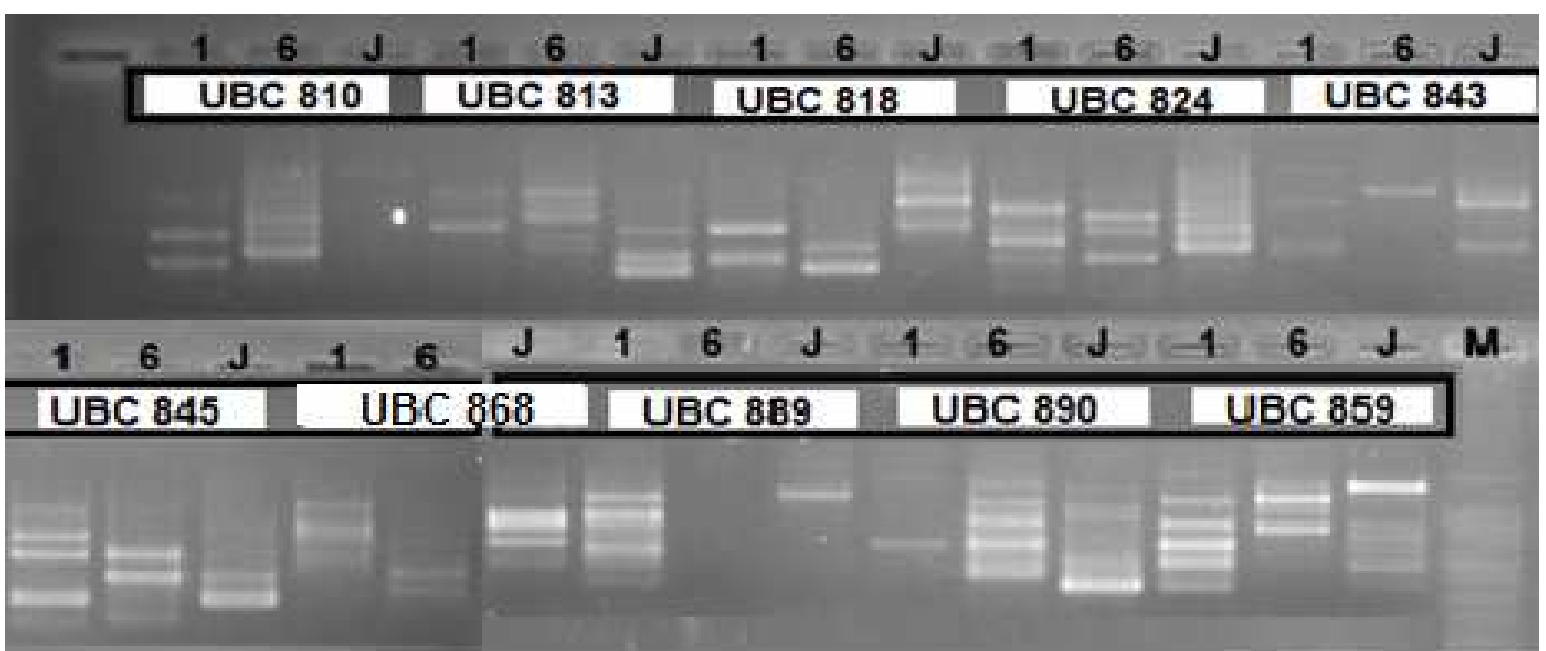

FIGURA 3: Teste de amplificação dos dez iniciadores ISSR para materiais 1 e 6 de café e J de jabuticabeira. Fonte: acervo pessoal dos autores , 2015.

\section{CONCLUSÕES}

A caracterização morfoagronômica quantitativa foi eficiente para estimar a diversidade genética entre as variedades, sendo importante ferramenta para 0 agrupamento das cultivares de café do Ifes Campus de Alegre.

A caracterização morfoagronômica qualitativa não possibilitou uma distinção adequada das variedades, sendo constatada grande uniformidade para os descritores utilizados, o que evidencia a necessidade de outros tipos de caracterizações para complementar os resultados.

Para a extração de DNA, foram obtidos três protocolos satisfatórios, sendo que o protocolo 3 apresentou bandas de DNA mais nítidas. Quanto à seleção dos iniciadores para caracterização molecular, foram selecionados UBC 813, 818, 824, 845 e 859 por apresentarem maior polimorfismo.

\section{REFERÊNCIAS}

AGUIAR, A.T.E.; GUERREIRO-FILHO, O.; MALUF, M.P.; GALLO, P.B.; FAZUOLI, L.C. Caracterização de cultivares de coffea arabica mediante utilização de descritores mínimos. Bragantia, Campinas, v.63, n.2, p.179-192, 2004. Disponível em: <http://www.scielo.br/pdf/\%0D/brag/v63n2/21367.pdf>. doi: 10.1590/S000687052004000200003.

BORÉM, A.; CAIXETA, E. T. Marcadores moleculares. 2ª Ed. Viçosa, 2009. 532p.

HEALEY, A.; FURTADO, A.; COOPER, T., HENRY, R.J. Protocol: a simple method for extracting next-generation sequencing quality genomic DNA from recalcitrant plant species. Plant Methods, 2014. Disponível em: < http://plantmethods.biomedcentral.com/articles/10.1186/1746-4811-10-21>. Doi: 10.1186/1746-4811-10-21.

CARVALHO, A.M.; MENDES, A. N., CARVALHO, G. R., BOTELHO, C. E., GONÇALVES, F. A., \& FERREIRA, A. D. Correlação entre crescimento e produtividade de cultivares de café em diferentes regiões de Minas Gerais, Brasil. ENCICLOPÉDIA BIOSFERA, Centro Científico Conhecer - Goiânia, v.13 n.23; p. 1002016 
Pesquisa agropecuária brasileira, v. 45, n. 3, p. 269-275, 2011. Disponível em: <http://seer.sct.embrapa.br/index.php/pab/article/view/7436>. Doi: 10.1590/S0100204X2010000300006.

CRUZ, C.D. Programa genes (versão Windows): aplicativo computacional em genética e estatística.Viçosa: UFV. 2008.

DIAS, F. P.; SOUZA, C. A. S. Caracterização de progênies do cafeeiro (Coffea arabica L.) selecionadas em Minas Gerais: II-caracteres relacionados à produção. Ceres, v. 52, n. 299, 2015. Disponível em: < http://www.ceres.ufv.br/ojs/index.php/ceres/article/view/3029>. Doi: 10.1590/S0034737X2011000300011

DIAS, R.E.B.A.; DA SILVA, F.M.; CUNHA, J.P.B.; AVELAR, R.C.; FERNANDES, F.C. Eficiência da colheita mecanizada do café com uso do inibidor de biossíntese de etileno. Coffee Science, v. 9, n. 4, p. 527-536, 2014. Disponível em: < http://www.coffeescience.ufla.br/index.php/Coffeescience/article/viewFile/746/pdf_13 $5>$.

DOYLE, J.J.; DOYLE J.L. Isolation of plant DNA from fresh tissue. Focus, v.12, p.1315, 1990.

FERRAO, R. G.; DA FONSECA, A. F. A.; SEBASTIÃO, J.; SILVEIRA, M.; FERRÃO, M. A. G.; BRAGANÇA, S. M. EMCAPA 8141-robustão capixaba, variedade clonal de café conilon tolerante à seca, desenvolvida para o estado do Espírito Santo. Ceres, 47:273-279, 2015.2 Disponível em: <http://www.ceres.ufv.br/ojs/index.php/ceres/article/view/2622>. Doi: $123456789 / 1266$

HEALEY, A.; FURTADO, A.; COOPER, T., HENRY, R.J. Protocol: a simple method for extracting next-generation sequencing quality genomic DNA from recalcitrant plant species. Plant Methods, 2014. Disponível em: <http://plantmethods.biomedcentral.com/articles/10.1186/1746-4811-10-21>. Doi: 10.1186/1746-4811-10-21.

IPGRI - International Plant Genetic Resource Institute.Descriptors for coffee (Coffea spp. and Psilanthus spp.). Roma, 1996.

JACOMINI, R.; BACHA, C.J.C.; FERRACIOLI, K.G. Comparação entre as políticas de café do Brasil e da Etiópia a partir de 1990. Revista de Política Agrícola. Ano XXIV, $\quad \mathrm{n}$ 1, $2015 . \quad$ Disponível em: $<$ https://seer.sede.embrapa.br/index.php/RPA/article/view/963>. Doi: s/doi.

MALLER, A.; REZENDE, R.; BRANDÃO, D.; TAVORE, R.V. Variação do diâmetro de caule de duas cultivares de cafeeiro sob fertirrigação e regimes hídricos. In: Alberto e Torres, A cultura cafeeira, $1^{\circ}$ edição, 2011.

MOSLEMI, M.; MEHDI, Z. , YOUNES, S.; GHOLAMREZA, B.K. Optimization of DNA extraction and amplified fragment length polymorphism (AFLP) analysis of pomegranate (Punica granatum L.). African Journal of Biotechnology. V. 12(34), 
pp.

5252-5257.

2013.

Disponível

em:

http://search.proquest.com/openview/b7f614431cae76e1f69f6bd3e6cbd684/1 ?pq-

origsite=gscholar $>$. Doi: 10.5897/AJB12.511.

MOULIN, M.M.; RODRIGUES, R.; GONÇALVES, L.S.A.; SUDRÉ, C.P.; GONZAGA, M.P. A comparison of RAPD and ISSR markers reveals genetic diversity among sweet potato landraces (Ipomoea batatas (L.) Lam). Acta Scientiarum. Agronomy (Impresso) . Vol. 34, p. 139-147, 2012. Disponível em: < http://www.scielo.br/scielo.php?pid=S180786212012000200004\&script=sci_arttext\&tl ng=es>. Doi: http://dx.doi.org/10.4025/actasciagron.v34i2.12616.

PEREIRA, G.S.; PINHO, E.V.R.V.; PADILHA, L.; VILELA, L.R.; CARVALHO, B.L.; PINHO, I.V.V. Coleta de folhas do cafeeiro e extração de DNA genômico de alta qualidade. VI Simpósio de Pesquisa dos Cafés do Brasil, 2009. Disponível em: <http://ainfo.cnptia.embrapa.br/digital/bitstream/item/44122/1/Coleta-de-folhas-docafeeiro.pdf>.

RONCAL, J., GUYOT, R., HAMON, P., CROUZILLAT, D., RIGOREAU, M., KONAN, O. N. G., ... \& DE KOCHKO, A. Active transposable elements recover species boundaries and geographic structure in Madagascan coffee species. Molecular Genetics and Genomics, p. 1-14, 2015. Disponível em: <http://link.springer.com/article/10.1007/s00438-015-1098-3>. doi: 10.1007/s00438015-1098-3.

SERENO, M.L.; ALBUQUERQUE, P.S.B.; VENCOVSKY, R.; FIGUEIRA, A. Genetic diversity and natural population structure of cacao (Theobroma cacao L.) from the Brazilian Amazon evaluated by microsatellite markers. Conservation Genetics. 7:13-24, 2006. Disponível em: < http://link.springer.com/article/10.1007/s10592-0057568-0\#/page-1>. Doi: 10.1007/s10592-005-7568-0.

TOMAZ, M. A.; SAKIYAMA, N. S.; DA MATTA, F. M.; MARTINEZ, H. E. P.; CRUZ, C. D.; PEREIRA, A. A. Efeito do porta-enxerto nas trocas gasosas, área foliar e superfície de raiz de mudas de coffea arabica I. Ceres, v. 53, n. 306, 2015. Disponível em: < http://www.redalyc.org/articulo.oa?id=305226787013>. Doi: 305226794015.

WAHYUNI, Y., BALLESTER, A. R., TIKUNOV, Y., VOS, R. C. H., PELGROM, T. B. K., MAHARIJAYA, A., SUDARMONOWATI, E., BINO, J. R., BOVY, A. G. Metabolomics and molecular marker analysis to explore pepper (Capsicum $\mathrm{sp}$.) biodiversity. Metabolomics, v. 9, p. 130-144, 2013. Disponível em: < http://link.springer.com/article/10.1007/s11306-012-0432-6\#/page-1>. Doi: 10.1007/s11306-012-0432-6. 